\title{
Short Women's Prayers in Spoken Ladino During three Times of Crisis
}

\author{
Nitsa Dori ${ }^{1}$ \\ ${ }^{1}$ Head of the Department of Early Childhood, Shaanan Academic College, Haifa, Israel \\ Correspondence: Nitsa Dori, Head of the Department of Early Childhood, Shaanan Academic College, Haifa, Israel.
}

Received: November 25, 2019

Accepted: December 11, 2019

Available online: December 24, 2019

doi:10.11114/ijsss.v8i1.4663

URL: https://doi.org/10.11114/ijsss.v8i1.4663

\begin{abstract}
This article discusses a limited number of ritual incantations or short prayers, used by Ladino-speaking women during crises - birth, war, or drought. These prayers, transmitted from one woman to another, were chosen because they are absent from the two major recent books on women's prayers - Aliza Lavie's A Jewish Woman's Prayer Book (2008), which includes women's prayers from different ethnic communities, some in Ladino, and Ora (Rodrigue) Schwarzwald's Seder Nashim (2012), prayers from a sixteenth century Ladino prayer book. This article seeks to document those short prayers before they are lost. They are quoted directly from Ladino-speaking informers, and discuss their life experiences, cultural norms, and individual discomforts.
\end{abstract}

Keywords: women's prayers, Ladino, women informers, incantations, Spanish Jewry

\section{Literary Review}

The exclusion of women from the male religious ritual led them to pray in their own language during times of trouble and crisis at their own initiative. Women's prayers in the oral tradition are personal, but also part of the entire community of women in the cultural setting where they were composed. They reflect a Jewish-Spanish life story where females suffered from life's troubles - birth and death, victory and defeat, life and drought.

Women, who did not have the benefit of a religious education or learning Hebrew, were excluded from the prayers in the canonical prayer book. Once Jews moved to Israel, Modern Hebrew superseded the many Jewish languages, 'uniform' prayers overrode many of the old women's prayers, and 'uniform' prayer books replaced the unique women's prayer books. Each prayer and supplication was different but had one common denominator - a dialogue with the Creator, hope for a better future, and fear for the family's well-being. This article presents the voices of the silenced women, their almost-lost works, and their dialogue that traverses cultures, so we can encounter the Sephardi-Jews' prayers. Throughout the generations women dared to innovate prayer frameworks and forms that resulted in new content, and religious understanding.

Public prayer by and for women was always blocked and silenced, as was women's place in public prayer in particular and Jewish ritual in general. However, important laws of prayer were learned from Hannah's prayer (I Samuel I). In practice, women can be full partners in the prayer process (Yisraeli \& Evron, 2008).

Prayer is an essential need. A person cannot stop his thoughts and feelings, doubts and troubles, longing and yearning. It is impossible to halt his emotional expressions. However, there is also a historical precedent for prayer. Cain, and later the forefathers, Moses, and the prophets fell pleading before God, told Him their thoughts, asked Him to help with their needs, and even begged and argued with Him. This is despite the fact that a limited person stands before an infinite God, whose Glory fills the entire world, and he is tiny in comparison. Likewise, Judaism does not see any difference between men and women, since both the forefathers and foremothers prayed to God.

\section{A General Review of Women's Prayer Books}

The parallel to the Ladino women's prayer book (also printed in the sixteenth century), to be discussed in the next section, is the Tzenah U'rena Yiddish prayer book. Tzenah U'rena or Teitch-Humash [a Yiddish Pentateuch] is a Yiddish book for Jewish women about the Bible, written by Jacob ben Isaac Ashkenazi in 1616.

Several books have been published that discuss women's prayers. For example, that by Guren Klirs (1992) includes a collection of Yiddish prayers and supplications by women and the laws applying to them, along with English translations. Cardin (1999) contains a collection of prayers for special occasions. Cardin's other book (1992) includes the wording of a prayer written by Dr. Josepha Cohen to his wife in 1786, preserved in the Jewish Theological 
Seminary's library. The book includes a selection of prayers for women and customs she should observe, all in vowelized Hebrew. Many of the texts have special names, and do not correspond to the regular prayers in standard prayer books. Weissler (1998) includes Yiddish supplications for women that have been translated into English over time. The book by Umansky and Ashton (1992) also includes collections of poems, supplications, diaries, and prayers by individual women, composed between 1560 and 1990. None are from standard prayer books.

\section{A Jewish Woman's Prayer Book and Seder Nashim - Reference to Women's Prayer in Ladino}

Lavie's book, A Jewish Woman's Prayer Book (2006) that collects together women's prayers from different Jewish communities, including some from Ladino culture, is divided into seven parts. 'A Locked Garden - Moments in a Woman's Life', 'Barrenness and Fertility', 'Prayers for Mothers', 'Women's Mitzvot' [commandments], 'Festivals and Holy Days', 'Times of Crisis', and 'Prayers for Peace and Redemption'. Around half of the sixty pages of the chapter 'Moments in a Woman's Life' are connected with finding a marriage partner and marriage.

The second chapter, 'Barrenness and Fertility' is divided into subsections. 'Fertility Prayers' - five prayers for having sons. (Aside from one that also mentions daughters, all specify male children.) These are followed by additional chapters concerning childbirth. Then prayers for mothers. That is, the book assumes a lifecycle of being a girl, bride, fertile woman, and mother. The chapter: 'Women's Commandments' also continues the chain - Lighting [Sabbath and festival] Candles, Separating Halla [from dough], and Immersion and Purification [laws regarding a married woman's ritual immersion after menstruation]. The chapter: 'Festivals and Holy Days' includes an explanation regarding allocating roles on the night of the New Year for Trees, "the girls make a blessing over the pomegranate and nut, following the verse [Ps. 45:14] "All the glory of the king's daughter is within"”.

According to Seri-Levi (2006), most of the book discusses finding a husband, pregnancy, and childbearing. Even the final chapter, 'Prayers for Peace and Redemption', includes a 'prayer for a childless woman at the graves of the righteous to merit a male child'. Although the book also sometimes includes new and innovative prayers, such as 'Prayer for a Woman Prior to Torah Study' and 'Prayer for Jewish Women who have been Murdered by their Spouses', written by Dr. Yael Levine, they are not sufficient to change the general direction of the prayers. The book in this form conserves and intensifies philosophies about femininity and offers a 'bear hug' to all kinds of feminism, including Orthodox feminism.

The book even maintains and reproduces negative stereotypical perspectives of women and femininity. For example, the last prayer in this chapter, 'Prayer of a Mother-in-Law' includes a supplication for the mother-in-law not to be jealous, nor any vice lurk within her. Emphasizing this aspect of a woman's life strengthens misogynous stereotypes. Chava Pinchas-Cohen's prayer 'A Mother's Early Morning Prayer' also paints the mother as lacking a personality of her own, with her entire essence being the motherhood to which she devotes herself so that 'each of my children will be able to see his face within mine' (Seri-Levi, 2006).

Rodrigue Schwarzwald's Seder Nashim: A $16^{\text {th }}$ Century Prayer Book for Women in Ladino (2012) ${ }^{1}$ is a women's prayer book compiled during the sixteenth century. It testifies to the author's attempt to balance empowering the world of women with their status in the public and social setting of that time period. During the sixteenth century a Thessaloniki rabbi, Meir ben Shmuel Benbenishti, authored a prayer book for women to implement Maimonides's opinion that it was the father's or husband's obligation to teach the women of his house to observe the commandments (Maimonides, Mishne Torah, Sotah, 4:19). As would be expected, this initiative created certain friction: the entire prayer book testifies to the attempt made to balance empowering the religious world of women with her status in the public and social setting as a wife and mother. Therefore, the prayer book was compiled in the lingua franca of Ladino, rather than Hebrew, and the prayers are abbreviated - meaning the women could both be taught and would actually pray quickly, without neglecting caring for their children.

Seder Nashim is a new edition of this prayer book, transliterating the Ladino into Latin letters and translated into Hebrew for the first time. It is accompanied by detailed prefaces. It is constructed in a similar fashion to a men's prayer book, but is abridged in accordance with rabbinical rulings. The prayer book includes prayers and blessings for everyday and festivals, and detailed instructions for all areas of life, with the goal of turning the Jewish woman into a good, believing Jew. The book includes references in Hebrew and Spanish about the book, its content, and style, with a special chapter about language. Aside from the introduction, translated from Ladino, the prayer book contains no Hebrew. All prayers are translated into Ladino. There are only occasional Hebrew words - words that infiltrated into spoken Ladino.

Unlike women's prayer books in other languages (Judeo-Italian and Yiddish), or women's prayers, this book does not contain prayers and supplications women would say at times such as lighting Sabbath candles, ritually bathing, or giving birth. On the contrary, the prayer book notes in its comments that after lighting the Sabbath candles a women

${ }^{1}$ See also Rodrigue Schwarzwald (2010). 
does not need to say anything else - anything extra would merely detract. After this book, no other women's prayer books were ever published in Ladino.

The prayer book also includes the Passover Hagaddah (the Seder service was held only with women), but the Maggid section (reciting the story of the Exodus) was truncated. Since women are not obligated in all prayers and commandments, the author abbreviated the prayers in line with other rabbinic decisors. The detailed instructions are based on Jewish legal decisions of both the Code of Jewish Law and the Talmud.

The prefaces by the author, Rabbi Meir Benbenishti, are particularly interesting. He argues men do not teach the prayers to their wives and daughters because they think they will have difficulty learning to read, and are afraid they will spend too much time praying, at the expense of their families. He believes women can easily learn to read vowelized texts, and since they are not obligated to say all the prayers, they will not neglect their households. This is what he did with his own family, and he recommends that every Jewish man sit for a short time each evening and teach the women in his family the prayer book.

Most strikingly, there is no reference to either synagogue or community. The prayers recited only with a quorum of ten adult Jewish males are not mentioned. The prayer book is designed solely for a woman's use at home.

The book includes indices of the unique words in Ladino and Hebrew. This book's most important contribution is, of course, scientific - a comprehensive study of a historic text. The prayer book testifies to the religious practices of the women in that time and place - from a male perspective. However, despite the fact that the prayer book is aimed solely at women, men's existence cannot be ignored. The point of departure is the man's responsibility to educate the women of his family. As the author writes in the (Hebrew) preface: 'Every Jewish man must guide the members of his household in the service of God and warn and supervise them always that they not come to sin or iniquity.' The man fulfills his obligation when the woman prays. Meaning, the window opened on the woman's religious world - the understanding that a Jewish woman is entitled to a significant and relevant religious life - was defined and established by the male 'establishment'. The prayer book is usually intended for individual use at home and in the synagogue. But this one is clearly only designated for the home. The Thessaloniki prayer book was written by a man, a rabbi, who knew prayers and Jewish law. He edited the prayer book, and wrote guidelines and abbreviated forms throughout the order of prayers.

This prayer book provided Jewish women with the essentials of the commandments and daily prayers around the year and during life cycle events. Rabbi Meir Benbenishti was an enlightened figure in his time, and wished to advance women's status, education, and active participation in Jewish life. This is also evident in the Ferrara prayer book of 1552, and in the women's Ladino prayer book published by Lazar (1995, 113 [161A in the manuscript]).

This prayer book is clearly important to the Jewish woman, and greatly contributed to elevating her status. But it was also a one-time effort. Apparently, men did not view women's increased Jewish education favorably when they no longer needed the men's help. Perhaps the Sephardic rabbis also viewed the translation of the prayers as undesirable, since prayer is always preferred in Hebrew. In any event, this interesting prayer book was never reprinted, nor were other prayer books published in Ladino for women of Spanish origin.

\section{Findings and Discussion}

The short Ladino prayers presented in this chapter include mysticism and mystery, a type of short prayer that effect the listener beyond what can be sensed, and demand an immediate answer, for urgent protection or help, from a Supreme Being. They express belief that includes auspicious words for driving off evil, enemies, and those wishing to cause harm. They are not prayers of thanks, praise, or recognition of God's supremacy or glory, but rather short incantations seeking a solution to a current trouble. Mysticism in general, and Jewish mysticism in particular, are not natural and universal but rather discursive constructs created in the nineteenth and twentieth centuries which served to catalogue, evaluate, and explain the not necessarily interconnected range of cultural products and social structures (Huss, 2016). Meaning, the phenomena known as 'mysticism' in Jewish and other cultures, do not possess any particular common traits or characteristics distinguishing them from other phenomena. Mysticism developed in Europe and the USA at the close of the nineteenth century due to various interests and needs of the times, and served to organize and explain a variety of ceremonies, practices, and social groups. Things defined as 'mystic' have no common characteristics, with the exception of the premise of those using this category, that these phenomena came into being due to mystical experiences, a result of a direct and intense encounter between man and God or a transcendental reality (11-12).

The short Ladino prayers, here divided into three sections - the elimination of enemies and death, childbirth, and rain correspond to the three keys in Jewish tradition solely in the hands of God and not entrusted to an agent (Babylonian Talmud, Ta'anit 2a).

These three 'keys' are connected with the root of life at its three major stations - its beginning, existence, and end. The first key - that of the woman giving birth, the moment of birth and new life, is one of the wonders of existence. From a tiny 
reality, the fetus develops and increases in size many times over, until it emerges from the womb at the right moment.

A woman who has experienced birth, glows with the joy of creativity that envelops her; she becomes a partner with her Creator in creation. In contrast is the pain of the barren woman who waits for children, interwoven with hidden jealousy. She feels as if she has no place in the world, because her organs of motherhood and fertility were created for no reason. As Rachel said bitterly to Jacob, 'Give me children! Otherwise I am dead' (Gen. 30:1).

The second key - rain, sustaining life. Rains were created to infuse creation with life, maintain existence, give life through water that enables the growth of plants that are food for animals. 'The Lord will open for you His storehouse of goodness, the heavens, to provide rain for your land in its time' (Deut. 28:12). The prophet calls this birth, 'For just as the rain and snow descend from heaven and will not return there, rather it waters the earth and causes it to give birth and sprout and gives seed to the sower and food to the eater...' (Isa. 55:10). Here, too, there is emergence from the hidden to the revealed, from potential to actuality. Growth is rebirth for the seeds that decomposed in the earth, and life for the trees that lacked it and were deep in a winter hibernation. The seeds emerging from the soil and the trees blossoming after the rain are a joyous sign of life and a kind of 'resurrection' of our world, and thus we are able to make the connection - to the third key.

The third key - resurrection of the dead, the end of life, and hope. At the point people believe is the end, the close of life, Judaism teaches that burying the body is not its removal from the world, but rather a kind of sowing so it can sprout once more in the future.

Rain and childbirth cannot be completely determined ahead of time. We cannot know far in advance what the weather will be like on a particular date. Even in our times, with all the modern means of predicting weather from satellites or weather stations, we cannot predict more than four or five days in advance, because nothing is certain in nature. Sometimes, after people have already given up hope, the rains suddenly arrive, in contrast to calculations and statistical estimates. In the same way, birth cannot be totally ensured in advanced, with infertile women sometimes suddenly becoming pregnant after having despaired of ever doing so. Likewise, the keys have hidden powers that cannot be understood or known, beyond the revealed forces of nature.

The three keys that remain in the hands of the Creator even after the order of nature was determined, grant a person the choice of bringing changes with his prayer, to awaken and use the powers above connected to these keys. This is the secret of the power of the 'service of the heart' in prayer.

\section{Praying for the Elimination of Enemies and Protection from Evil}

This section includes the largest number of prayers, the motives for which will be discussed below. The chapter begins with two short Ladino prayers for elimination of enemies, and both include a request for revenge on the enemy, contradicting the spirit of Judaism that forbids a person to take revenge or bear a grudge and teaches a person to forgive any hurt ${ }^{2}$ :

'If someone wishes that evil befall me - may it be evil for him, may days come that he will be supported by my household'. ${ }^{3}$

'That my enemy not see my death, that he see me saved from any troubles'.

And other prayers:

‘_ (person's name), son of (mother's name), may he not have any evil or pain and may all his troubles go into the sea ${ }^{5}$ (a prayer recited three times while holding a fistful of salt and waving it over the body of the blessed person, followed by throwing the salt into running water).

'May God guard us from libel and any evil' (a prayer recited at the conclusion of the Sabbath, during the time when a blessing is made over the candle). ${ }^{6}$

'May he go to the enemies'.

\footnotetext{
${ }^{2}$ From the prayers before going to sleep: "Master of the Universe, I hereby forgive anyone who angered or antagonized me or who sinned against me. Whether against my body, my money, my honor, or anything I own. Whether he did so accidentally or willingly or mistakenly or deliberately, through speech or action. Whether in this transmigration or another, to every Jew and may no person be punished because of me."

${ }^{3}$ Ken me kere mal, mal tenga ora venga de mi kaza se mantenga.

${ }^{4}$ Mi enimigo no me vera murir de todo mal me vera salvar.

5 ------Ijo de-------ke no tenga dingun sar y dingun mal y todos los males ke se vaygan a la mar.

${ }^{6}$ El Dio ke mos guadre de aftira y de todo modo de mal.
} 
'I am sewing for the queen of France, that you should have her riches and she should have your hopes, thus it is incorrect, that they should not make false charges against you' (a prayer said to a person when sewing on a button or making another small repair when he is wearing the garment, due to the belief is that it is forbidden to sew when someone is wearing the item of clothing, and he needs to first remove it). ${ }^{8}$

'May he neither win nor achieve it'.

'You do no evil, and may no one do evil to you'10 (said to a person who was afraid of someone else, with a spoon of sugar in his mouth).

'May his strength and appetite be taken from him.'11

'I am going to sleep, and locking my doors with the keys of Miriam the prophetess and of King Solomon, of blessed memory'. 12

'I entrust my soul to God on High. My sleep and awakening will be good. Guard me from a bad friend, a bad neighbor, bad hours, evil thoughts, and evil plots'. 13

'May we not lie on our deathbeds for a long time, and may death come easily'. ${ }^{14}$

'Guard us from the evil eye and the evil eye' (once in Turkish, then in Ladino). ${ }^{15}$

'May the evil go and not come'. 16

'A deaf evil hour' (may the evil hour be deaf, if its sense of hearing is taken from it, it won't know that it is supposed to come). ${ }^{17}$

'May my eyes see good' (when a person blinks unintentionally, he touches his eye and says this incantation three times). ${ }^{18}$

To understand why there are so many prayers for eliminating enemies, the historiographic background of Ladino speakers should be studied, beginning with the Expulsion from Spain in 1492 up until the Ottoman Empire. Who did the Jews hate in this setting? Who were considered their enemies? The Jews arrived in a Muslim setting that granted them protection. But there were two trends regarding the Jews in Muslim tradition (Markus, 1992). One was tolerant, while the other was filled with hatred toward Judaism. This was particularly prevalent among Shia Muslims (who are loyal to the families of the Prophet Muhammad and his supporters). For them, anyone who is not Muslim is impure. The religious fanatics taught people to behave badly towards non-Muslims in the name of their prophet. They said they should avoid any cooperation with members of other religions. They denied that Muhammad had said, 'Whoever does an injustice to someone protected, is as if he does me an injustice'. How was the law from the Quran and later literature interpreted practically? The Muslim scholars did not dare change the ancient laws that were ascribed to the caliph Umar,

\footnotetext{
7 A los enimigos vayga. echen iftira.

${ }^{9}$ Ke no ayege ni itishtreye.

10 Ni mal azes ni mal ke no te agan.

${ }^{11}$ Ke se le tome el poder y la gana del komer. women added their own words.

14 Kama kurta y muerte livyana ke mos dye el Dio.

15 Guadrado de kaza y de ora mala.

16 El mal ke vayga y ke no venga.

${ }^{17}$ Sodra la ora mala.

${ }^{18}$ Mi ojo veyga bueno.
}

${ }^{8}$ Yo kuzgo ensima de la reyna de fransia ke tu tengas su bien y eya sera tu esperansa ansi ke no esverdad y ke no te

${ }^{12}$ A echar me echo sero mis puertas kon las yaves de Miriam la profeta y kon el sinior de Shlomo amelech alav ashalom. And see: A prayer 'At the Conclusion of Shabbat' for saying after drinking the first glass of water after the Sabbath has ended, in Lavie's book (2006, 230), that also mentions Miriam the prophetess.

13 Al Dio alto enkomendo mi alma buena sea mi echada, mas mijor mi alevantada, guadramos de haver malo, de vizino malo, de ora malas, de setensias malas y de hajizmas malas. (In Hebrew: a friend/ haver, and in Turkish: hajikmas). A prayer added to saying the Shema declaration before going to sleep. What is interesting is that the content and some of the words of this prayer are actually taken from morning prayers in the standard prayer book, but the Ladino-speaking 
regarding organization of the lives of Jews and Christians in the conquered lands. However, they were reinterpreted, positively or negatively, depending on the particular circumstances or the attitude of the specific ruler. Some Muslim rulers rejected the rigid rules of the Islamic scholars, and others were stringent in carrying out the letter of the law toward the People of the Book. The conquerors did not usually disturb their lives and wishes, on condition that they pay their special taxes as noted in the Quran (Surah 9:29). Those born in the conquered territories were given the status of dhimmis (protected people) who were required to pay special taxes - jizyah (poll tax) and kharaj (land tax). The Muslims had already abandoned the principal of forcing their beliefs on others through the fire and sword at the beginning of their conquest, and therefore needed to ensure their rule by reasonable means, expressed mainly in a contract known as the Pact of Umar (the second caliph, 634-644), although it originates from a later period. The Pact ordered the dhimmis to observe six basic conditions, with the goal of ensuring Muslim rule:

(1) Not to slander the Quran, Islam, or its prophets.

(2) Not to marry Muslim women.

(3) Not to persuade Muslims to abandon their beliefs.

(4) Not to harm Muslim lives or property.

(5) Not to aid their enemies.

(6) Not to protect spies.

Aside from these conditions, the dhimmis were required to observe six additional rules, with its aim clearly being humiliating the 'nonbelievers':

(1) To wear a yellow sign on their clothes and a special belt (zunar).

(2) Not to build houses higher than those of the Muslims.

(3) Not to use wooden bells or read holy writings loudly.

(4) Not to drink wine in public.

(5) Burial and mourning were to be quiet.

(6) Not to ride horses, but only mules and donkeys.

There are no reports of inquisitions in the history of the relationship between Muslims and Jews, but the Jews were humiliated, oppressed, and insulted over many generations. Islamic Judophobia was already long established by the nineteenth century, with its origins in the Quran and continuing in the Hadith, the Sunnah, and a long tradition of discrimination and even humiliation of the dhimmis, the Jewish (and Christian) protected people. There were persecutions and pogroms against the Jews in the Muslim countries throughout the generations, although they were usually less frequent and less violent than those in Christian countries (Wistrich, 2014). The Jews' official status under Islamic rule was almost always inferior, although there were periods characterized by some tolerance, calmness, and prosperity. These were mainly periods of cultural greatness, such as the Golden Age in Spain during the Middle Ages, and the period of the blossoming of the Ottoman Empire.

Yaron Tsur (2016) teaches that the semi-autonomous rulers who controlled the various districts of the empire sometimes amassed great power until the whim of someone high up led to their elimination. Those same rulers sometimes forged close alliances with rich or well-connected Jews to manage their finances - until they had enough of them, sometimes due to the intrigues or informing of their rivals. These were sometimes members of other minorities Greeks or Armenians - who wanted to take the positions from the Jew. The eliminations were Mafia-style. A messenger came to the home of Bachor Karmona and strangled him with his own scarf. Haim Parhi was strangled and his body thrown into the sea. There were principles that were upheld, such as the rule that Jews, as protected citizens of the Muslims, could not hold a position of authority. But during the period in which the book under discussion was compiled, the law seems to have existed in name only. In any event, in most of their places of residence the Jews lived between a rock and a hard place - particularly those whose livelihood depended on the benevolence of the rulers or others in positions of authority. They needed to endlessly manipulate themselves between loyalty to different people, and sometimes gambling on the wrong person cost the Jew his life.

In light of the above, the short prayers to eliminate haters and enemies that use many mechanisms for self-protection, curses against those harming the person, revenge, and grudge-bearing, and without forgiveness or loving peace, can be understood. ${ }^{19}$

\footnotetext{
${ }^{19}$ Two Ladino proverbs that were translated from racist proverbs in Turkish represent this section better than anything else: 'Where a Jew treads, no grass grows' and 'The Jew understands what he should do too late'. Another Ladino
} 


\section{Prayers for Childbirth}

Eastern cultures view death as an inseparable part of life, and denial of its existence as ignorance that causes suffering. The reasons Eastern cultures feel there is no reason to fear death are mostly connected to belief in reincarnation, and that a person does not have a 'self'. The encounter with death is part of every person's life, and the Jewish people, during its blood-soaked history, saw death both near and far more than others. The incredibly minor preoccupation with death within Jewish creation and the Jewish nation is a unique phenomenon. The personal encounter with death, that was, perhaps, the greatest test of character and culture, exists in many places in Jewish sources, but despite its many forms, there is a common aspect to all its manifestations - the encounter with death is also a moment of life, and an honorable death is that of a person who ends an honorable life. Death is the disease of life, a distortion and falsification within the holiness with which life is identified. With such courageous acceptance of death, when it is encountered there is also a stubborn battle with it on the cosmic plane, a war against death expressed in the essence of evil - 'it is the evil inclination, it is the Satan, it is the angel of death' say the Sages (Babylonian Talmud, Baba Batra 16a). And the endless struggle with the 'spirit of impurity' (Zech. 13:2) is not only against ethical evil, but even more so against the greatest defect in the world, death itself.

In the past, one of the most common causes of death at a young age was childbirth. People did not possess today's technological means and medical advances and the childbearing woman's life was in danger from the moment the birth process or even pregnancy began, until after the actual birth. If we add the cases in which women could not achieve pregnancy, perhaps because of a minor problem that could easily be treated today, but which once caused infertility, the precious nature of each pregnancy and the significance of every birth will be easily understood.

The concept of 'birth' is borrowed regarding the formation and creation of various things such as the creation of the world, forming ice and frost, inclinations, and thoughts, as well as educating children - birth was not just viewed as a technical biological process but rather a spiritual one of creation and formation. The childbearing woman is also called chaya (Midrash Ecclesiastes Rabba 3), meaning living or an animal, and there are various descriptions that emphasize the danger and time of judgement encountered during birth 'a time to give birth and a time to die' (Eccles. 3:2). According to Judaism, women die during childbirth because they are careless about three commandments - ritual immersion, separating halla, and lighting Sabbath and festival candles (Babylonian Talmud, Shabbat 31b). The woman giving birth is defined in Jewish law as a sick person whose life is in danger and for whom it is permissible to desecrate the Sabbath (ibid., 128b). The Bible includes descriptions of several births, some particularly difficult, such as Rachel's birth to Benjamin which ended in her death.

Three short prayers said to women while giving birth:

'May God help her with one cry'. ${ }^{20}$

'A good ending' (a good saving). ${ }^{21}$

'That her portion should be with the good women who gave birth' (that she should give birth easily). ${ }^{22}$

All three express both fear for the woman's fate, while also containing the emotive words based on the premise that words create reality, and are only positive - 'help' (in the first) and 'good' (in the second and third). ${ }^{23}$

\section{The Jewish Women's Prayers for Rain}

From the beginning of Jewish culture, rain has always been a sign of Godly favor, and a means of examining the Jewish nation's dependent relationship with God. Throughout the Jewish people's history in its land, rain was always part of

proverb that shows the Jew's wish not to harm someone who hadn't harmed him is 'A snake that doesn't bite me should live for a thousand years' and another that shows how dangerous people are, more than a beast of prey, 'Better a lion pounce on you, than the evil eye of man'.

20 El Dio ke la eskape kon una boz.

${ }^{21}$ Eskapamiento bueno.

${ }^{22}$ El Dioke la meta entre las bien paridas.

${ }^{23}$ The proverb in Ladino, 'La mujer paridera al guerko es vensadera' [the woman who has already had children overcomes Satan] shows how the fear of a woman who hasn't had children is nullified. And the proverb, 'Pregnancy is a gift, giving birth is a bad step, and raising children is chewing iron' also demonstrates how the difficulty of giving birth is viewed by those who speak Ladino. The proverb, 'Le dezea la alma de la prenyada agranada agra y yinyeve tostada' [the pregnant woman wants a sour pomegranate and roasted snow] demonstrates the pregnant woman's desires that are difficult to fulfill. Another proverb describes the pain of giving birth, 'Ni luvia sin tureuelos ni parto sin dolor' [there is no rain without thunder, and no birth without pain]. 
the conversation between man and his Creator, through its arrival or lack, such as the story of seven years of drought with a miraculous end during the time of Elijah (1 Kings 18). The religious discourse between the people and its God about the rain continued during the Second Temple period. The Talmud and Midrash mention individuals who brought rain, such as Honi the Circle-Drawer, and there are discussions regarding what characteristics are demanded of someone who 'brings rain'. Tractate Taanit in the Babylonian Talmud devotes its entire first chapter to the process of prayer, fasting, and supplications required in a drought year.

The High Priest's prayer on the Day of Atonement, according to the Sephardic liturgical song 'Ata Connanta' utilizes this ethical philosophy, 'If this year was going to be a drought, may You make it rainy. And may the prayers of the travelers regarding rain not be accepted before You when Your nation, Israel, needs it.' This prayer emanates from pain over drought, and true familiarity with the critical need for rain.

Once the Jews were in Exile, particularly in Europe, the personal and close relationship between the Jewish world and agriculture and the rain that sustained it gradually dissolved. With the return of the Jewish nation to its land, the Israeli agricultural society was renewed, and despite the sophisticated water supply system, it still requires rain, with great importance being attached to it in Israeli society and culture.

Judaism sees a direct connection between a lack of rain and infertility, noted above. The 'feminine approach' in literary texts on the topic creates a parallel between rain and drought and the personal feminine womb, and more broadly, the entire male-female relationship, from both emotional and physiological aspects. Many poems in Hebrew literature, for example, compare a woman to the earth awaiting the rain that fertilizes, emanating from a deep, rooted connection not only with the earth but also with herself, her feelings, and internal wisdom. This is the Jewish-Israeli approach, influenced by the biblical equation that depicts rain as a favorable time, and drought as God hiding His face and being angry. The difference between them lies not in the point of departure, but in the way of looking at that same 'favorable time'. Male reading interprets it as a cosmetic, external, worldwide repair, but female reading takes that same 'favorable time' to the most personal and intimate part of the woman within herself. The prayer for rain found in the standard prayer book and recited in the Mussaf service of the last day of the Tabernacles holiday, includes difficult words, that reflect struggle, sadness, and suffering, and discusses only male figures:

'For blessing and not for a curse!

For life and not for death!

For plenty and not for famine!'

In Ladino, the prayers said by heart by the women are softer and gentler:

'God, the earth wants water'. ${ }^{24}$

'Children and infants want bread'.

'Merciful One, Merciful One, send wheat to the world'.

This prayer is also connected with the Ladino blessing for children, 'that they not be lacking, like bread and water. ${ }^{, 25}$ The same material elements in prayers for a year of drought become a blessing for children - that children will not be lacking, like bread and water. Drawing a parallel between what is most precious to parents - their children - and basic foods - bread and water - emphasizes the importance of the latter. How does this short prayer connect with early stories about rain in Judaism?

The Talmud relates the power of the prayer by Abba Hilkia and his wife during a time without rain. ${ }^{26}$ Abba Hilkia was the grandson of Honi the Circle-Drawer, and he therefore enjoyed the merit of his forefathers so that God would answer his prayer. When hired for the day, he didn't want to speak to the Sages while working, so as not to steal his employer's time. Later, Abba Hilkia says to his wife, 'I know the Sages have come to request rain. Let us go up to the attic and pray for it before they ask us, maybe God will answer us and there will be rain and they won't feel indebted to us.' They went up to the roof, he on one side and she on the other. The clouds came from his wife's side. After rain fell, Abba Hilkia came down and asked the Sages why they had come. They asked him why the clouds had come from his wife's side first. He answered them, 'Because a woman is at home, and when a poor person asks for food, she gives him food and I give him money. After I have given, the poor person remains hungry until he finds something to buy, but when

\footnotetext{
${ }^{24}$ Agua Dio la tiera demanda, chikos y pekenios pan keremos. Arigador arigador nanda trigo al mundador

${ }^{25}$ Ke no manken komo el pan y la agua.

${ }^{26}$ Babylonian Talmud, Taanit 23a-23b.
} 
she gives he eats immediately and relieves his hunger.' He also told them there had been thugs in his neighborhood who had bothered him. He prayed they would die and she prayed they would repent, and they repented.

We again learn the Sages' view of the power of women's prayers. In this short Ladino prayer for rain, that sprouted from the female home setting and not from the rabbis, we return to the story of Abba Hilkia's wife. The regular prayer book includes prayers for rain. But perhaps it is actually the simple woman, at home, who will succeed in bringing rain with a short and innocent prayer, from the heart, and begging for water for the dry earth and the little children, and these prayers will have more success than the organized, written prayers.

\section{Summary}

Women in general, and Sephardic Jewish women in particular, were excluded in various ways from the communal ritual. What was common to them was the great need and thirst for the experience of prayer, and the shared characteristics, that express deep feelings and enable moments of elation and holiness, of expressing their worries, sadness, anxiety, even for those who had not been educated to pray or were used to being excluded. The personal prayers presented in this article, recited by heart, and the shared experience when women said them, touched an important emotional component of Sephardic Jewish female identity in the religious setting of the world of prayer in the oral tradition.

\section{References}

Cardin, N. B. (1992). Out of the depths I call to you: A book of prayers for the married Jewish woman. Lanham, MD: Jason Aronson.

Cardin, N. B. (1999). Tears of sorrow, seeds of hope: A Jewish spiritual companion for infertility and pregnancy loss. Nashville, TN: Jewish Lights.

Guren, K. T. (1992). The merit of our mothers: A bilingual anthology of Jewish women's prayers. Hebrew Union College.

Huss, B. (2016). She'elat kiyumah shel mistikah yehudit [The question of the existence of Jewish Mysticism]. Jerusalem: The Van Leer Jerusalem Institute and Kibbutz Hameuhad.

Lavie, A. (2008). A Jewish woman's prayer book. New York: Spiegel \& Grau.

Lazar, M. (Ed.). (1995). Siddur tefillot: A woman's Ladino prayer book. Lancaster: Labyrinthos.

Markus, S. (1993). Sinat hayehudim b'islam [Antisemitism in Islam]. Mahanaim 76.

Rodrigue, S. O. (2010). Two sixteenth-century Ladino prayer books for women. European Judaism, 43, 37-51. https://doi.org/10.3167/ej.2010.430205

Rodrigue, S. O. (2012). Sidur para mujeres en Ladino. Salónica, Siglo XVI. Edición anotada y traducida [Seder Nashim: A 16th Century Prayer Book for Women in Ladino]. Jerusalem: Yad Itzhak Ben-Zvi.

Seri-Levi, G. (2006). Tefilat nashim, pasifas nashi shel tefilot v'sipurim [Review of women's prayers, a feminine mosaic of prayers and stories, by Aliza Lavie]. Retrieved from http://www.e-mago.co.il/Editor/feminism-921.htm

Tsur, Y. (2016). Gvirim viyehudim aherim bemizrah hatikhon ha'otemani 1750-1830 [Notables and other Jews in the Ottoman Middle East 1750-1830]. Jerusalem: Bialik Institute.

Umansky, E. M., \& Ashton, D. (1992). Four centuries of Jewish Women's spirituality: A sourcebook. Waltham, MA: Brandeis University Press.

Weissler, C. (1998). Voices of the matriarchs: Listening to the prayers of Early Modern Jewish women. Boston, MA: Beacon.

Wistrich, R. S. (2014). The changing face of Antisemitism. Retrieved from https://mida.org.il/2014/04/27/\%D7\%A4\%D7\%A0\%D7\%99\%D7\%94-\%D7\%94\%D7\%9E\%D7\%A9\%D7\%AA\% D7\%A0\%D7\%95\%D7\%AA-\%D7\%A9\%D7\%9C-\%D7\%A9\%D7\%A0\%D7\%90\%D7\%AA-\%D7\%94\%D7\%99\% $\mathrm{D} 7 \% 94 \% \mathrm{D} 7 \% 95 \% \mathrm{D} 7 \% 93 \% \mathrm{D} 7 \% 99 \% \mathrm{D} 7 \% 9 \mathrm{D} /$

Yisraeli, A., \& Evron, D. (2008). Lomdot tefilah mihanah [Women’s Melody: Learning Prayer from Hannah]. Deot, 36.

\section{Copyrights}

Copyright for this article is retained by the author(s), with first publication rights granted to the journal.

This is an open-access article distributed under the terms and conditions of the Creative Commons Attribution license which permits unrestricted use, distribution, and reproduction in any medium, provided the original work is properly cited. 